\title{
TINJAUAN YURIDIS PENDEKATAN HOLISTIK MELALUI PENDEKATAN HOLISTIK MELALUI TINDAKAN STREOTIP DAN PERKEMBANGANNYA
}

\author{
Juan Fetrix Manurung \\ Email: juanfetrix28@gmail.com \\ No BP: 2110003600291 \\ Universitas Ekasakti Padang
}

\section{A. PENDAhuluan}

Kebudayaan merupakan unsur penting dalam keberlanjutan suatu bangsa, kemajemukan budaya bangsa Indonesia tercermin dalam berbagai aspek kehidupan dengan latar belakang sosio budaya yang beranekaragam. Keanekaragaman budaya yang ada membuktikan bahwa masyarakat memiliki kualitas produksi budaya yang luar biasa, jika mengacu pada pengertian kebudayaan adalah hasil cipta manusia.

Masyarakat dan kebudayaan dimanapun selalu dalam keadaan berubah baik perubahan jumlah dan komposisi di lingkungan sendiri, perubahan lingkungan alam dan fisik tempat mereka hidup, adanya difusi kebudayaan, penemuan-penemuan baru baik teknologi dan inovasi. Masyarakat memiliki kebudayaan hubungan/kontak dengan kebudayaan dengan orangorang yang berasal dari luar masyarakat tersebut. Suatu unsur kebudayaan diterima jika sebelumnya sudah ada unsur-unsur kebudayaan yang menjadi landasan bagi diterimanya unsur kebudayaan yang baru tersebut dapat dengan mudah dibutuhkan kegunaannya oleh warga masyarakat yang bersangkutan Masyarakat sebagai pemilik kesenian dan pendukung kebudayaan bersifat dinamis. Namun kenyataannya perubahan-perubahan yang terjadi dalam rentang waktu hidup beberapa generasi manusia tidak sama cepatnya antara kelompok manusia satu dengan manusia lainnya, mereka berkembang mengikuti perubahan zaman 
yang menyangkut pola pikir, rasa mampu tingkah laku perkembangan ilmu pengetahuan dan teknologi meluasnya tata pergaulan hidup masyarakat. Dalam hal ini dapat di lihat bahwa:

1. Masyarakat adalah kesatuan hidup manusia yang berinteraksi menurut system adat istiadat tertentu yang bersifat kontinyu, dan terikat oleh sesuatu rasa identitas bersama;

2. Sistem budaya atau kultural sistem merupakan ide-ide dan gagasan manusia yang hidup bersama dalam suatu masyarakat, meliputi adat istiadat yang mencakup sistem nilai budaya, nilai norma, norma-norma menurut pranatapranata yang ada di dalam masyarakat yang bersangkutan, termasuk norma agama.

Justru dalamhal ini pendekatan-pendekatan yang ada dalam antropologi hukum yang besifat holistik ini akan menjadi acuan penting bagi perumusan masalah dalam kehidupan bermasyarakat,sosial,budaya bahkan norma-norma yang berkembang dalam kehidupan sehari-hari. Permasalahan-permaslahan dengan strereotipe kehidupan sehari-hari adalah bagaimana pelakasanaan tersebut dapat menjadi acuan penting dalam mengidentifikasi masalah yang ada dalam antropologi hukum itu sendiri.

Kecenderungan seseorang atau suatu kelompok untuk memiliki stereotip terhadap kelompok lain dapat mempengaruhi interaksi antara keduanya. Berkembangnya stereotip tersebut bisa menjadi potensi yang menghambat dalam komunikasi antar-budaya. Kesalahpahaman-kesalahpahaman antar-budaya seperti ini dapat dikurangi apabila setiap kelompok atau daerah setidaknya mengetahui bahasa dan perilaku budaya orang lain, serta mengetahui prinsip-prinsip komunikasi antar-budaya dan mempraktikannya dengan bertoleransi dalam kehidupan sehari-hari.

Sebagaimana aspek dari stereotipe memiliki pengaruh terhadap seseorang untuk melakukan prasangka sosial, menurut Sobur (2013) prasangka sosial terbentuk selama 
perkembangannya, baik melalui didikan maupun dengan cara identifikasi dengan orang lain yang sudah berprasangka. Hal ini berlangsung dengan sendirinya dan pada taraf tidak sadar melalui proses imitasi, sugesti, identifikasi dan simpati, yang memegang peranan utama dalam interaksi sosial itu. Dalam kaitan ini, secara tidak sadar mereka lambat laun memperoleh sikap-sikap tertentu terhadap golongan-golongan tertentu, yang pada gilirannya dapat melahirkan stereotipe-stereotipe.

\section{B. PEMBAHASAN}

Menurut Kamus Besar Bahasa Indonesia, pengertian tinjauan adalah mempelajari dengan cermat, memeriksa (untuk memahami), pandangan, pendapat (sesudah menyelidiki, mempelajari, dan sebagainnya). Menurut Kamus Hukum, kata yuridis berasal dari kata yuridisch yang berarti menurut hukum atau dari segi hukum. Dapat disimpulkan tinjauan yuridis berarti mempelajari dengan cermat, memeriksa (untuk memahami), suatu pandangan atau pendapat dari segi hukum.

Pengertian Tinjauan Yuridis menurut hukum pidana, adalah dapat disamakan dengan mengkaji hukum pidana materil yang artinya kegiatan pemeriksaan yang teliti terhadap semua ketentuan dan peraturan yang menunjukkan tentang tindakan - tindakan mana yang dapat dihukum, delik apa yang terjadi, unsur - unsur tindak pidana terpenuhi, serta siapa pelaku yang dapat dipertanggungjawabkan terhadap tindak pidana tersebut dan pidana yang dijatuhkan terhadap pelaku tindak pidana

Istilah tindak pidana merupakan terjemahan dari istilah Belanda yaitu strafbaar feit. Disamping istilah tindak pidana sebagai terjemahan strafbaar feit itu, dalam bahasa Indonesia terdapat juga istilah lain yang dapat ditemukan dalam beberapa buku hukum pidana dan 
perundang-undangan hukum pidana, yaitu peristiwa pidana, perbuatan pidana, perbuatan yang boleh dihukum, perbuatan yang dapat dihukum, dan pelanggaran pidana.

Antropologi adalah ilmu tentang manusia. Antropologi berasal dari kata Yunani anthropos yang berarti manusia atau orang, dan logos yang berarti wacana (dalam pengertian bernalar, berakal atau secara etimologis antropologi berarti ilmu yang mempelajari manusia. Dalam melakukan kajian terhadap manusia, antropologi mengedepankan dua konsep penting yaitu: Holistik dan Komparatif. Karena itu kajian antropologi sangat memperhatikan aspek sejarah dan penjelasan menyeluruh untuk menggambarkan manusia melalui pengetahuan ilmu sosial ilmu hayati (alam), dan juga humaniora.

Dengan orientasinya yang holistik, antropologi dibagi menjadi empat cabang ilmu yang saling berkaitan, yaitu: Antropologi Biologi, Antropologi Sosial Budaya, Arkeologi, dan Linguistik. Keempat cabang tersebut memiliki kajian-kajian konsentrasi tersendiri dalam kekhususan akademik dan penelitian ilmiah, dengan topik yang unik dan metode penelitian yang berbeda-beda.

Ada tujuh periode penting dalam perkembangan antropologi hukum. Periode yang pertama terjadi pada tahun 1860an ketika Sir Henry Maine yang sedang bertugas di India menerbitkan Ancient Law yang merangkum berbagai tradisi hukum dan mengembangkan teori bahwa setiap masyarakat yang berkembang akan mengalami perubahan dari versi primitifnya menuju masyarakat Victoria. Pandangan Maine tentu dapat dicap rasis dalam konteks modern karena memuliakan peradaban Eropa.

Di pertengahan abad ke-20, antropolog-antropolog memperdebatkan penggunaan pendekatan pengkategorian hukum Anglo-Amerika dalam mengkaji masyarakat-masyarakat non-Barat. Dua tokoh utama dalam perdebatan ini ialah Max Gluckman dan Paul Bohannan. 
Bohannan meyakini bahwa pengkategorian berdasarkan hukum Anglo-Amerika membatasi pemahaman dan keterwakilan budaya lain dan lebih menyukai penggunaan istilah setempat yang belum tentu konsepnya dapat diterjemahkan ke dalam bahasa Inggris tetapi dapat dijelaskan. Sementara itu Gluckman menilai pendekatan Bohannan tersebut terlalu berhatihati dan justru menjadi penghalang dalam menghasilkan analisis perbandingan.

Terkait dengan fungsi disiplin ilmu antropologi sendiri, menjadi hal unik untuk dikaji tentang sudut pandang antropologi yang membedakannya dengan antropologi hukum. Pada suatu perbandingan, jika antropologi hukum lebih menitikberatkan suatu budaya hukum yang berkaitan atau mempengaruhi masalah hukum (aspek yang melatar belakangi hukum dan penyelesaiaan hukum). Pada sudut pandang yang berbeda, antropologi memandang suatu fenoma sosial yang terjadi dimasyarakat dengan mengakitkan pada nilai, norma, adat, tradisi, dan budaya yang berada dikehidupan masyarakat tersebut. Antropologi menempatkan fungsinya sebagai disiplin ilmu yang memakai perspektif budaya (mengedepankan nilai-nilai budaya) dalam penyelesaian masalah kehidupan sosial manusia.

Sedangkan ruang lingkup manusia khusus budaya (bermasyarakat) lebih mengarah tingkah laku manusia. Dimana dalam antropologi lebih sering disebut Antropologi Budaya berhubungan dengan apa yang sering disebut dengan Etnologi. Ilmu ini mempelajari tingkahlaku manusia, baik itu tingkah-laku individu atau tingkah laku kelompok. Tingkah-laku yang dipelajari disini bukan hanya kegiatan yang bisa diamati dengan mata saja, tetapi juga apa yang ada dalam pikiran mereka. Pada manusia, tingkah-laku ini tergantung pada proses pembelajaran. Apa yang mereka lakukan adalah hasil dari proses belajar yang dilakukan oleh manusia sepanjang hidupnya disadari atau tidak. Mereka mempelajari bagaimana bertingkahlaku ini dengan cara mencontoh atau belajar dari generasi diatasnya dan juga dari lingkungan 
alam dan social yang ada disekelilingnya. Inilah yang oleh para ahli Antropologi disebut dengan kebudayaan.

Kebudayaan dari kelompok-kelompok manusia, baik itu kelompok kecil maupun kelompok yang sangat besar inilah yang menjadi objek spesial dari penelitian-penelitian Antropologi Sosial Budaya. Dalam perkembangannya Antropologi Sosial-Budaya ini memecah lagi kedalam bentuk-bentuk spesialisasi atau pengkhususan disesuaikan dengan bidang kajian yang dipelajari atau diteliti. Antroplogi Hukum yang mempelajari bentukbentuk hukum pada kelompok-kelompok masyarakat atau Antropologi Ekonomi yang mempelajari gejala-gejala serta bentuk-bentuk perekonomian pada kelompok-kelompok masyarakat adalah dua contoh dari sekian banyak bentuk spesialasi dalam Antropologi Sosial-Budaya.

Kesenian sebagai bagian dari masyarakat akan senantiasa hidup baik sebagai ekspresi pribadi maupun bersama kelompok masyarakat, tumbuh kembangnya suatu kesenian akan selaras dengan kepentingan masyarakat itu sendiri. Setiap unsur peradaban dalam kesenian, selalu mengalami proses perubahan yang berbeda-beda. Adakalanya berkembang atau mengalami kemunduran akibat dorongan dari dalam maupun sebagai akibat pengaruh luar masyarakat itu sendiri.

Masyarakat merupakan suatu kesatuan masyarakat yang diikat oleh norma-norma hidup karena sejarah, tradisi maupun agama Menurut Karkono Kamajaya, budaya yaitu perwujudan budi manusia yang mencakup kemauan, cita-cita, ide dalam semangat untuk mencapai kesejahteraan, keselamatan, kebahagian lahir dan batin. Ini dapat disimpulkan bahwa: 
1. Masyarakat adalah kesatuan hidup manusia yang berinteraksi menurut system adat istiadat tertentu yang bersifat kontinyu, dan terikat oleh sesuatu rasa identitas bersama;

2. Sistem budaya atau kultural sistem merupakan ide-ide dan gagasan manusia yang hidup bersama dalam suatu masyarakat, meliputi adat istiadat yang mencakup sistem nilai budaya, nilai norma, norma-norma menurut pranatapranata yang ada di dalam masyarakat yang bersangkutan, termasuk norma agama.

Stereotipe adalah penilaian terhadap seseorang hanya berdasarkan persepsi terhadap kelompok di mana orang tersebut dapat dikategorikan. Stereotipe merupakan jalan pintas pemikiran yang dilakukan secara intuitif oleh manusia untuk menyederhanakan hal-hal yang kompleks dan membantu dalam pengambilan keputusan secara cepat. Namun, stereotipe dapat berupa prasangka positif dan juga negatif, dan kadang-kadang dijadikan alasan untuk melakukan tindakan diskriminatif. Sebagian beranganggapan bahwa segala bentuk stereotipe adalah negatif.

Miles Hewstone dan Rupert Brown (dalam Liliweri, 2005) mengemukakan tiga aspek yang terdapat dalam stereotipe, yaitu :

a. Kategorisasi, merupakan suatu kondisi dimana acap kali keberadaan individu dalam suatu kelompok telah disusun berdasarkan kategori kelompok tertentu dan pengelompokkan itu selalu teridentifikasi dengan mudah melalui karakter atau sifat tertentu, misalnya perilaku, kebiasaan bertindak, seks dan etnisitas.

b. Turun-temurun, merupakan suatu sistem untuk membentuk stereotipe berdasarkan sifat perilaku, sehingga setiap individu dalam kelompok seolah-olah melekat pada semua anggota kelompok. 
c. Karakteristik, merupakan sesuatu yang khas atau mencolok dari individu yang merupakan anggota dari suatu kelompok tertentu, karakteristik yang dimaksud seperti ciri khas dari kebiasaan bertindak yang sama dengan kelompok yang digeneralisasi itu.

\section{PENUTUP}

Pendekatan holistik merupakan cabang pendekatan dari antropologi hukum yang melihat bagaimana skema kehidupan masyrakat di lihat secara menyeluruh dan juga komprehensif dalam kehidupan masyarakat Masyarakat merupakan suatu kesatuan masyarakat yang diikat oleh norma-norma hidup karena sejarah, tradisi maupun agama Menurut Karkono Kamajaya, budaya yaitu perwujudan budi manusia yang mencakup kemauan, cita-cita, ide dalam semangat untuk mencapai kesejahteraan, keselamatan, kebahagian lahir dan batin. Tiap kebudayaan yang hidup dalam suatu masyarakat bisa menampilkan suatu corak khas kebudayaan terutama terlihat oleh orang luar yang belum warga masyarakat yang bersangkutan. Corak khas dari suatu kebudayaan bisa tampil karena kebudayaan itu menghasilkan suatu unsur yang kecil berupa unsur kebudayaan fisik dengan bentuk yang khusus atau karena diantara pranata-pranatanya ada suatu pola sosial khusus sehingga berdasarkan atas corak khusus tadi maka suatu kebudayaan dapat dilihat dari kebudayaan lainnya dalam keberlangsungan budaya sebagai penentu nilai-nilai terbaik baik dari dalam maupun dari luar masyarakat.

Kemudia pendekatan Stereotipe adalah penilaian terhadap seseorang hanya berdasarkan persepsi terhadap kelompok di mana orang tersebut dapat dikategorikan. Stereotipe merupakan jalan pintas pemikiran yang dilakukan secara intuitif oleh manusia untuk menyederhanakan hal-hal yang kompleks dan membantu dalam pengambilan 
keputusan secara cepat. Namun, stereotipe dapat berupa prasangka positif dan juga negatif, dan kadang-kadang dijadikan alasan untuk melakukan tindakan diskriminatif. Pendekatan ini acap kali selalu bersifat negatif tetapi sebenarnya Meskipun stereotip pada umumnya adalah streotipe yang negatif tetapi juga memiliki suatu fungsi, antara lain Menggambarkan suatu kondisi kelompok tertentu Memberikan dan membentuk citra kepada kelompok Membantu seseorang dari suatu kelompok untuk mulai bersikap terhadap kelompok lainnya Melalui stereotip ini kita dapat menilai keadaan suatu kelompok. 


\section{DAFTAR PUSTAKA}

Darmini Roza dan Laurensius Arliman S, Peran Pemerintah Daerah Di Dalam Melindungi Hak Anak Di Indonesia, Masalah-Masalah Hukum, Volume 47, Nomor 1, 2018. https://doi.org/10.14710/mmh.47.1.2018.10-21

Laurensius Arliman S, Peranan Metodologi Penelitian Hukum di Dalam Perkembangan Ilmu Hukum di Indonesia, Soumatera Law Review, Volume 1, Nomor 1, 201. http://doi.org/10.22216/soumlaw.vli1.3346.

Laurensius Arliman S, Peran Badan Permusyawaratan Desa di Dalam Pembangunan Desa dan Pengawasan Keuangan Desa, Padjadjaran Journal of Law, Volume 4, Nomor 3, 2017. https://doi.org/10.15408/jch.v4i2.3433.

Laurensius Arliman S, Penanaman Modal Asing Di Sumatera Barat Berdasarkan UndangUndang Nomor 25 Tahun 2007 Tentang Penanaman Modal, Supremasi Hukum, Volume 1, Nomor 1, 2018. http://dx.doi.org/10.36441/hukum.v1i01.102.

Laurensius Arliman S, Memperkuat Kearifan Lokal Untuk Menangkal Intoleransi Umat Beragama Di Indonesia, Ensiklopedia of Journal, Volume 1, Nomor 1, 2018, https://doi.org/10.33559/eoj.v1i1.18.

Laurensius Arliman S, Perkawinan Antar Negara Di Indonesia Berdasarkan Hukum Perdata Internasional, Kertha Patrika, Volume 39, Nomor 3, 2017, https://doi.org/10.24843/KP.2017.v39.i03.p03.

Laurensius Arliman S, Partisipasi Masyarakat Di Dalam Pengelolaan Uang Desa PascaUndangUndang Nomor 6 Tahun 2014 Tentang Desa, Jurnal Arena Hukum, Volume 12, Nomor 2, 2019, https://doi.org/10.21776/ub.arenahukum.2019.01202.5.

Laurensius Arliman S, Mewujudkan Penegakan Hukum Yang Baik Di Negara Hukum Indonesia, Dialogica Jurnalica, Volume 11, Nomor 1, 2019, https://doi.org/10.28932/di.v11i1.1831.

Laurensius Arliman S, Mediasi Melalui Pendekatan Mufakat Sebagai Lembaga Alternatif Penyelesaian Sengketa Untuk Mendukung Pembangunan Ekonomi Nasional, UIR Law Review, Volume 2, Nomor 2, 2018, https://doi.org/10.25299/uirlrev.2018.vol2(02).1587

Laurensius Arliman S, Peranan Filsafat Hukum Dalam Perlindungan Hak Anak Yang Berkelanjutan Sebagai Bagian Dari Hak Asasi Manusia, Doctrinal, Volume 1, Nomor 2,2016.

Laurensius Arliman S, Ni Putu Eka Dewi, Protection of Children and Women's Rights in Indonesiathrough International Regulation Ratification, Journal of Innovation, Creativity and Change Volume 15, Nomor 6, 2021.

Laurensius Arliman S, Gagalnya Perlindungan Anak Sebagai Salah Satu Bagian Dari Hak Asasi Manusia Oleh Orang Tua Ditinjau Dari Mazhab Utilitarianisme, Jurnal Yuridis, Volume 3, Nomor 2, 2016, http://dx.doi.org/10.35586/.v3i2.180.

Laurensius Arliman S, Tantangan Pendidikan Kewarganegaraan Pada Revolusi 4.0, Jurnal Ensiklopedia Sosial Review, Volume 2, Nomor 3, $2020 .$. 